Review Article

\title{
A REVIEW ON CHEMICAL CONSTITUENTS AND BIOLOGICAL ACTIVITIES OF THE GENUS PICRORHIZA (SCROPHULARIACE)
}

\author{
ANJU BHATNAGAR
}

\author{
D. B. S. (P. G.) College Dehradun (India) 248001
}

Email: dbsanju2014@gmail.com

Received: 04 May 2021, Revised and Accepted: 02 Jul 2021

\begin{abstract}
Picrorhiza (family Scrophulariace), commonly known as 'kukti' is a small perennial herb found in the Himalayan regions of China, Pakistan, India, Bhutan and Nepal at an altitude of 3000-5200 m. Different plant parts and its extract have traditionally been used as a remedy of various ailments such as fever, asthma, jaundice, anemia, abdominal pain, dysentery, cold, stomach problems. Picrorihza has been investigated for its chemical composition and biological activities by various researchers. The major chemical constituents found in this plant were iridoid glycosides, cucurbitacins (triterpenoids) glycosides, phenylethanoid glycosides and phenolics. The Picrorihza has various pharmacological properties, including hepto-protective, antimicrobial, anti-mutagenic, cardio-protective, anti-malarial, anti-diabetic, anti-cancer, anti-inflammatory, anti-ulcer, and neuroprotective and antioxidant activities. A thorough bibliographic investigation was carried out by analyzing worldwide scientific databases including Pub Med, Science Direct, Google Scholar and Wiley online as well as offline sources. The Present review is aimed to provide an updated overview of traditional uses, chemical constituents and biological activities of Picrorihza to explore its therapeutic potentials and to provide bases for future research
\end{abstract}

Keywords: Picrorihza, Traditional uses, Phytochemistry, Biological activity, Chemical constitutents

(C) 2021 The Authors. Published by Innovare Academic Sciences Pvt Ltd. This is an open access article under the CC BY license (https://creativecommons.org/licenses/by/4.0/)

DOI: https://dx.doi.org/10.22159/ijcpr.2021v13i5.1901 Journal homepage: https://innovareacademics.in/journals/index.php/ijcpr

\section{INTRODUCTION}

Natural products have been commonly used as an herbal drug for the treatment of various diseases and disorders from ancient times [1-3]. Natural products are substances or chemical compounds produced by living organisms, usually plants, that have many pharmacological activities [4-7]. Plants produce the vast and diverse array of structurally different organic compounds or secondary metabolites. Biosynthesis of the secondary metabolites is strongly affected by different abiotic and biotic factors. The stress conditions affects secondary metabolites or active ingredients that the plants produce, which are usually the basis for their medicinal activity [89]. Secondary metabolites have a wide spectrum of uses ranging from flavoring agents to medicinal values [10]. Thus, natural products (secondary metabolites) have been utilized in both traditional and modern medicine for treating various diseases [1116]. The majority of rural population mainly depends upon the medicinal plants as a source of remedies [17-20].

The Genus Picrorhiza is well known for its medicinal values belonging to the family Scrophulariaceae having two important endangered medicinal plant species, Picrorhiza kurrooa Royle ex Benth and Picrorhiza scrophulariiflora Pennel, native of India, Nepal, China, Tibet and Pakistan. P. kurroa (Vernacular name-kutki) is predominant in the western Himalayas of Northern India, while $P$. scrophulariiflora is mainly occure in the Himalayan regions of Sikkim, Nepal and Tibet. In India genus Picrorhiza is distributed in alpine region of Kashmir to Sikkim Himalayas [21, 22].

In Ayurvedic medicine system, Picrorhiza is generally used for treatment of disorder of the liver, upper portion of the respiratory tract; to reduce fever, chronic diarrhea, dyspepsia, and scorpion sting [23]. There have been many reports to show a wide spectrum of biological activities having therapeutic importance of its extract and constitutents [24-27]. Different formulations of Picrorrhiza Kurroa extract and constituents are available viz-Kutku root powder, Picrorrhiza kurroa standardized extract containing 7-14\% kutkin, Liver support and Arogya vardhani, etc. Picroliv, a standardized mixture of iridoid glycoside, prepared from alcoholic extract of Picrorhiza Kurroa root and rhizome has shown strong hepatoprotective activity against the liver damage caused by various hepato-toxins, it has also been investigated as anti-anaphylactic and anti-allergic $[28,29]$. Picrorhiza Kurroa root and rhizome contain kutkin as active constitutent. Other identified active constituents are apocyanine, androcine and cucurbitacine glycoside [30,31]. The constituents of Picrorhiza kurroa are reported to show a number of pharmacological activities such as hepatoprotective, anti-allergic, immunemodulatory properties, free radical scavenging, gastric ulcer, anti-allergic and many more [32-35]. P. scrophulariiflora is used for antioxidant and antiradical activities, antidiabetic, anti healing, antiasthmatic, cardioprotective, anticancer and antiulcer activity [36-40].

This study presents the current update on phytochemistry, medicinal uses, biological activities and toxicities of P. kurroa to reveal their pharmacological potentials and lacking that offer scope for future research.

\section{About the genus picrorhiza}

The Picrorhiza is small genera belonging to the family Scrophulariaceae, having two species namely P. kurroa Royle ex Benth and P. Scorophulariflora Pennell. The name Picrorhiza is derived from the Greek word'picro'and 'rhiza', which means bitter root and it is used in native medicine. The specific name derived from Karu, the Punjabi name of the plant, which means bitter as well [41]. P. kurroa is a vulnerable, perennial medicinal herb prevalent in alpine region. The plant grows in Himalayan region in moist rock crevices as well as in organic soils. It grows typically on cliffy and sloppy mountains. It is chiefly abundant in Himalayan province i.e. from Garhwal to Bhutan, north Burma, west China and southeast Tibet. The species is found in large quantities in high altitudes ranged between 3000 to $5000 \mathrm{~m}$ [42]. The roots of P. kurroa are inflexible, almost 6-10 inches long, creeping and bitter in taste. The leaves are oval-shaped, 2-4 inches long, with a sharp apex or serrated. The flowers are pale purple or white in colour, occurring on a long spike. Furthermore, the fruit is about $1 / 2$ inch long and oval shaped. P. Scorophulariiflora is a species located in the moist eastern Himalayas having short stamens and a bilabiate corolla, upper lip of which is longer and the lower lip consists of three shorter lobes while P. Kurroa has long stamens with a short corolla and five subequal lobes [43]. 


\section{Chemical constituents of picrorhiza}

The main chemical constituents' isolated different parts of Picrorhiza species are listed and their bioactivities are described to demonstrate the development in the phytochemistry and therapeutic applications of Picrorhiza genus.

\section{Iridoid glycosides}

Medicinally important iridoid glycosides have been isolated and characterized from Picrorhiza: Picroside I, Picroside II, Picroside-III, Picroside-IV, Picroside-V, Veminoside, Catalpol, Veronicoside, Specioside, 6-feruloylcatalpol, Pikuroside, Aucubin etc $[44,45]$. These iridoids belong to the family of terpenoids which has more than 30,000 members possessing important biological and physiological functions in plants. Kutkin and picroliv are the main herbal preparation of P. kurroa; Kutkin is a mixture of picroside I and kutkoside in a ratio of 1:2 and other minor glycosides whereas Picroliv is a similar but less purified fraction, containing about $60 \%$ of an equal mixture of Picrozide-I and kutkoside [46-48].

\section{Cucurbitacins}

These are triterpenoid compounds containing a cucurbitane skeleton characterized as 93-methyl-19-nor lanosta-5-ene,. Cucurbitacins possess a wide range of biological activities and the present in the form of $\beta$-glycosides in plants. A large number of cucurbitacin glycosides have been isolated from Picrorhiza species, mainly from P. kurroa $[49,50]$.

\section{Phenolics}

They are precursors and degradation products of lignin, which provide sturdiness to the plant and a physical defense barrier against parasites. Various phenolics isolated from P. kurroa are vanillic acid, apocynin, androsin and picein $[50,51]$.

\section{Phenylethanoid glycoside}

P. scrophulariiflora contains cyclopentanoid monoterpenes, caffeoyl glycosides, phenylethanoid glycoside and plantamajoside [52, 53].

The major classes of chemical compounds isolated from Picrorhiza species-P. kurroa (P. K) and P. Scorophulariiflora (P. S) are listed in table 1.

Table 1: Chemical constituents Isolated from picrorhiza species and bioacitives

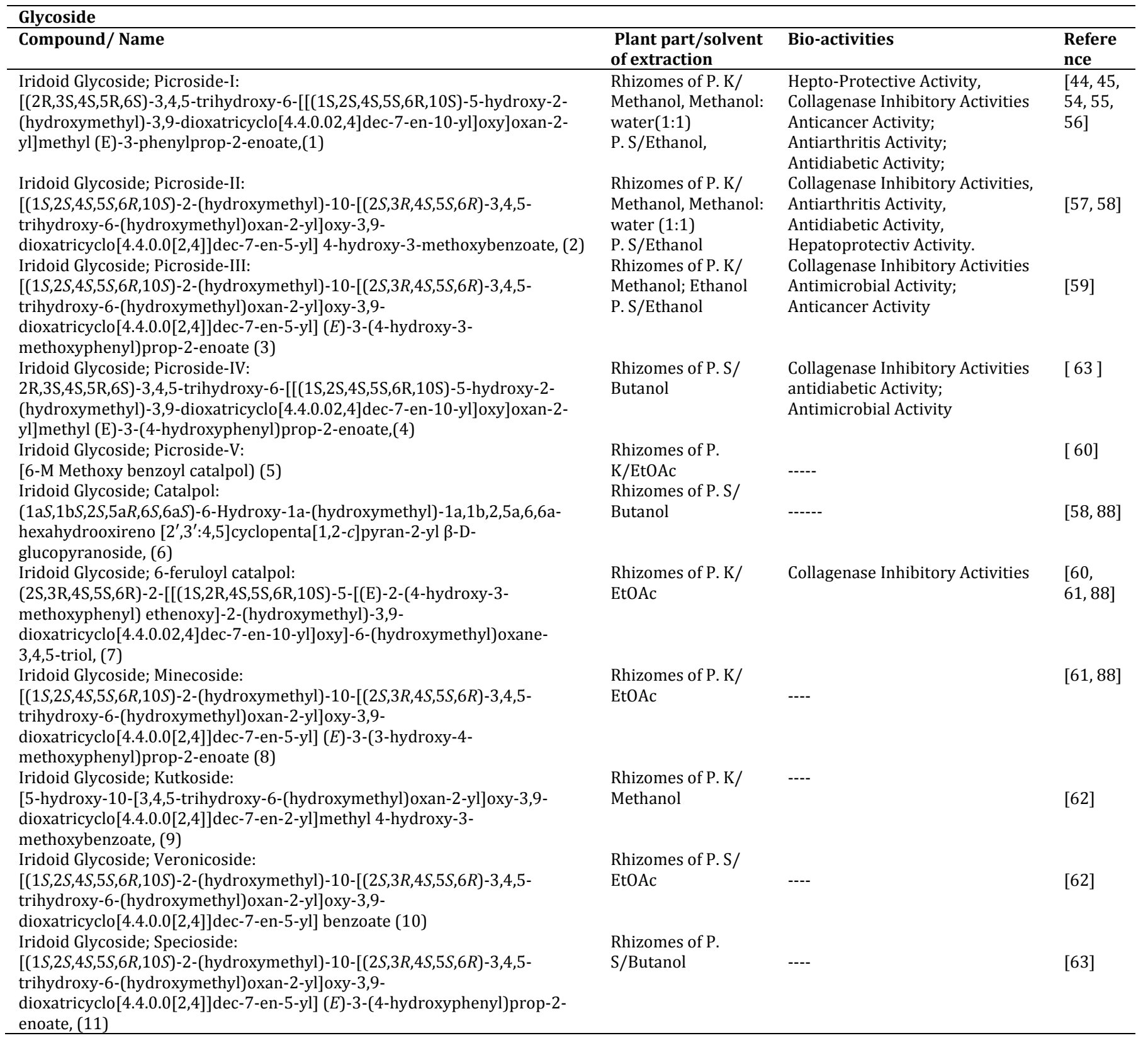




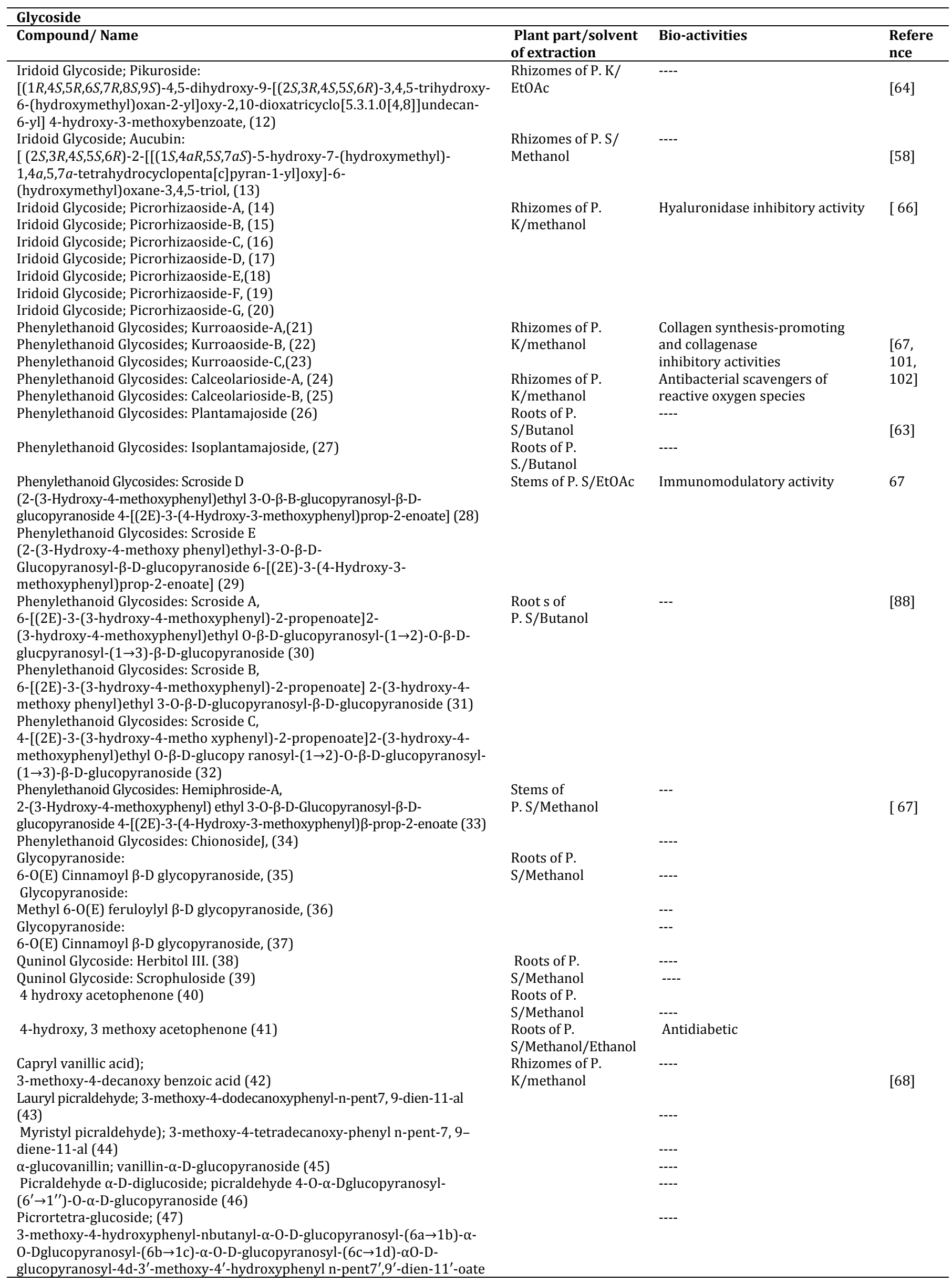




\begin{tabular}{|c|c|c|c|}
\hline \multicolumn{4}{|l|}{ Glycoside } \\
\hline Compound/ Name & $\begin{array}{l}\text { Plant part/solvent } \\
\text { of extraction }\end{array}$ & Bio-activities & $\begin{array}{l}\text { Refere } \\
\text { nce }\end{array}$ \\
\hline Iridoid Glycoside; Abeloside A (48) & Stems of P. K/n- & Anti-Vpr activity & {$[69$} \\
\hline Iridoid Glycoside; Abeloside B, (49) & butanol & & 104] \\
\hline \multicolumn{4}{|l|}{ Iridoid Glycoside; Sylvestroside IV dimethyl acetal, (50) } \\
\hline \multicolumn{4}{|l|}{ Iridoid Glycoside; Sweroside, (51) } \\
\hline \multicolumn{4}{|l|}{ Iridoid Glycoside; 8-Epi-Loganin, (52) } \\
\hline \multicolumn{4}{|l|}{ Iridoid Glycoside; 8-Epi-Loganic acid, (53) } \\
\hline \multicolumn{4}{|l|}{ Bis-Iridoid Glycoside; Saungmaygaoside A, (54) } \\
\hline \multicolumn{4}{|l|}{ Bis-Iridoid Glycoside; Saungmaygaoside B, (55) } \\
\hline \multicolumn{4}{|l|}{ Bis-Iridoid Glycoside; Saungmaygaoside C, (56) } \\
\hline \multicolumn{4}{|l|}{ Bis-Iridoid Glycoside; Saungmaygaoside D, (57) } \\
\hline \multicolumn{4}{|l|}{ Cucurbitacins glycosides } \\
\hline 2-0-glycoside of cucurbitacin B: (25-acetoxy-2-beta-glucosyloxy-16,20- & Roots of P. K/EtOAc & & \\
\hline dihydroxy-9-methyl-19-norl anosta-5, 23-diene-3,11,22-trione) (58) & & ----- & [65] \\
\hline \multicolumn{4}{|l|}{ 2-0-glucoside of 23,24 didydrocucurbitacin B: (25-acetoxy-2-beta- } \\
\hline $\begin{array}{l}\text { glucosyloxy-16,20-dihydroxy-9-methyl-19-norl anost-5-ene-3, 11-22- } \\
\text { trione) (59) }\end{array}$ & & ---- & \\
\hline \multicolumn{4}{|l|}{$\begin{array}{l}\text { 2-beta-glucosyloxy-3,16,20,25-tetrahydroxy-9-methyl-19-norlanos ta-5, 23- } \\
\text { diene-22-one, (60) }\end{array}$} \\
\hline \multicolumn{4}{|l|}{$\begin{array}{l}\text { 2-beta-glucosyloxy-3,16,20,25-tetrahydroxy-9-methyl-19-norlanos t-5-ene- } \\
22 \text {-one, (61) }\end{array}$} \\
\hline \\
\hline \multicolumn{4}{|l|}{ 3,16,20-trihydroxy-9-methyl-19-norlanosta-5, 23-diene-11,22-dione), (62) } \\
\hline \multirow{2}{*}{\multicolumn{4}{|c|}{$\begin{array}{l}\text { 2-0-glucoside of deacetoxycucurbitacin B (2-beta-glucosyloxy-16,20- } \\
\text { dihydroxy-9-methyl-19-norlanosta-5, 24-diene-3,11,22-trione) (63) }\end{array}$}} \\
\hline & & & \\
\hline \multicolumn{4}{|l|}{ Arvenin III: } \\
\hline & Roots of P. & & [70] \\
\hline $\begin{array}{l}\text { diene-11,22-dione and } 2 \beta \text {-glucosyloxy-16,20, 22-trihydroxy-9-methyl-19- } \\
\text { norlanosta-5,24-diene-3,11-dione, are new and one, (64) }\end{array}$ & K/Butanol & & \\
\hline $\begin{array}{l}2 \beta \text {-glucosyloxy-3,16,20,25-tetrahydroxy-9-methyl-19-norlanosta-5,23- } \\
\text { diene-11,22-dione }(65)\end{array}$ & & ---- & \\
\hline $\begin{array}{l}\text { 2- } \beta \text {-glucosyloxy-16,20,22-trihydroxy-9-methyl-19-norlanosta-5,24-diene- } \\
\text { 3,11-dione (66) }\end{array}$ & & ----- & \\
\hline $\begin{array}{l}\text { 25-(acetyloxy)-2-( } \beta \text {-D-glucopyranosloxy)-3,16,-dihydr oxy-9-methyl-19- } \\
\text { norlanosta-5 23-dien-22-one (67) }\end{array}$ & Roots of $\mathrm{P}$ K/EtOAc & & {$[62]$} \\
\hline 25 -(acetyloxy)-2-( $\beta$-D-glucopyranosyloxy)-3,16,20-trihydr oxy-9-methyl- & KOOLS OI P. K/ELUAC & $-\cdots$ & [63] \\
\hline 19-nor lanosta-5, 23(Z)-dien-22-one (68) & & & \\
\hline 25-(acetyloxy)-2-( $\beta$-D-glucopyranosyloxy)-3,16,20-trihy droxy-9-methyl- & & ---- & \\
\hline 19-norlanost-5-en-22-one (69) & & & \\
\hline $\begin{array}{l}\text { 2-( } \beta \text {-D-glucopyranosyloxy)-3,16,20 trihydroxy-9-methyl-19-norlanosta-5, } \\
\text { 24-dien-22-one (70) }\end{array}$ & & ---- & \\
\hline $\begin{array}{l}\text { 2-( } \beta \text {-D-glucopyranosyloxy)-3,16-dihydroxy-4,4,9,14-tetra methyl-19- } \\
\text { norpregn-5-en-20-one (71) }\end{array}$ & & ---- & \\
\hline 2,3,16,20,25-pentahydroxy-9-methyl-19-norlanost-5-en-22-one (72) & & ---- & \\
\hline $\begin{array}{l}\text { 2-(6-0-cinnamoyl- } \beta \text {-D-glucopyranosyloxy)-3,16,20, 25-tetrahydroxy-9- } \\
\text { methyl-19-norlanost-5-en-22-on (73) }\end{array}$ & & ---- & \\
\hline$(2 \beta, 9 \beta, 10 \alpha, 16 \alpha, 20 \epsilon, 24 \epsilon)-20,24$-epoxy-2-( $\beta$-D-glucopyranosyloxy)-16,25- & Roots of P. & ---- & \\
\hline dihydroxy-9-methyl-19-norl anost-5-ene-3,11-dione (74) & $\mathrm{K} / \mathrm{methanol}$ & & {$[64]$} \\
\hline $2 \beta, 3 \beta, 9 \beta, 10 \alpha, 16 \alpha, 20 \epsilon, 24 \epsilon)-20,24$ epoxy-2-( $\beta-D-$ & & & \\
\hline $\begin{array}{l}\text { glucopyranosyloxy)3,16,25-trihydroxy-9-methyl-19-norla nosta-5-ene-11- } \\
\text { one (75) }\end{array}$ & & ----- & \\
\hline$(2 \beta, 9 \beta, 10 \alpha, 16 \alpha, 20 \epsilon, 24 \epsilon)-20,24$-epoxy-2-( $\beta$-D-glucopyrano-syloxy)- & & $-\cdots--$ & \\
\hline 16,25,26-trihydroxy-9-methyl-19-norlanost-5-en-3,11-dione (76) & & & \\
\hline$(2 \beta, 3 \beta, 9 \beta, 10 \alpha, 16 \alpha, 20 \epsilon, 24 \epsilon)-20,24$-epoxy-2-( $\beta$-D-glucopyranosyloxy)-3,16, & & $--\cdot-$ & \\
\hline 25, 26-tetrahydroxy-9-methyl-19-norlanost-5-en-11-one (77) & & & \\
\hline$(2 \beta, 9 \beta, 10 \alpha, 16 \alpha, 20 \beta, 24 Z)-2-(\beta-D$-glucopyranosyloxy)-16,20,26-trihydroxy- & & ---- & \\
\hline 9-methyl-19-norlanost-5,24-diene-3,11-dione (78) & & & \\
\hline $\begin{array}{l}(2 \beta, 9 \beta, 10 \alpha, 16 \alpha, 20 \beta, 24 Z)-2 \text {-( } \beta \text {-D-glucopyranosyloxy)-3,16,20, 26- } \\
\text { tetrahydroxy-9-methyl-19-norlnost-5,24-diene-11-one (79) }\end{array}$ & & ---- & \\
\hline Cucurbitane-type triterpene glycoside; Kurroaoside D, (80) & Roots of P. & Collagenase & \\
\hline & $\mathrm{K} /$ methanol & inhibitory activities & [67] \\
\hline Nortriterpene glycoside; 25 -acetoxy-2- $\beta$-D-glucopyranosyloxy-3,16,20- & Roots P. & Anti-tumorous activities and & \\
\hline trihydroxy-9-methyl-19-norlanosta-5-en-22-one, (81) & $\mathrm{K} / \mathrm{methanol}$ & collagenase inhibitory activities & [67] \\
\hline Phenolics & & & \\
\hline Vanillic acid: 4-hydroxy-3-methoxybenzoic acid (82) & Rhizomes of P. & & \\
\hline & $\begin{array}{l}\mathrm{K} / \text { methanol, P.S } \\
\text { with ethanol }\end{array}$ & ---- & [49] \\
\hline Ferullic acid: (E)-3-(4-hydroxy-3-methoxyphenyl) prop-2-enoic acid (83) & $\begin{array}{l}\text { Rhizomes of } \mathrm{P} \text {. } \\
\mathrm{K} / 95 \% \text { ethanol }\end{array}$ & ---- & {$[72,73]$} \\
\hline Isoferullic acid: (E)-3-(3-hydroxy-4-methoxyphenyl) prop-2-enoic acid (84) & $\begin{array}{l}\text { Rhizomes of } P \text {. } \\
\text { K/95\% ethanol }\end{array}$ & ---- & {$[72,73]$} \\
\hline Apocynin: 1-(4-Hydroxy-3-methoxyphenyl)ethan-1-one & Rhizomes of P. & & [74] \\
\hline
\end{tabular}




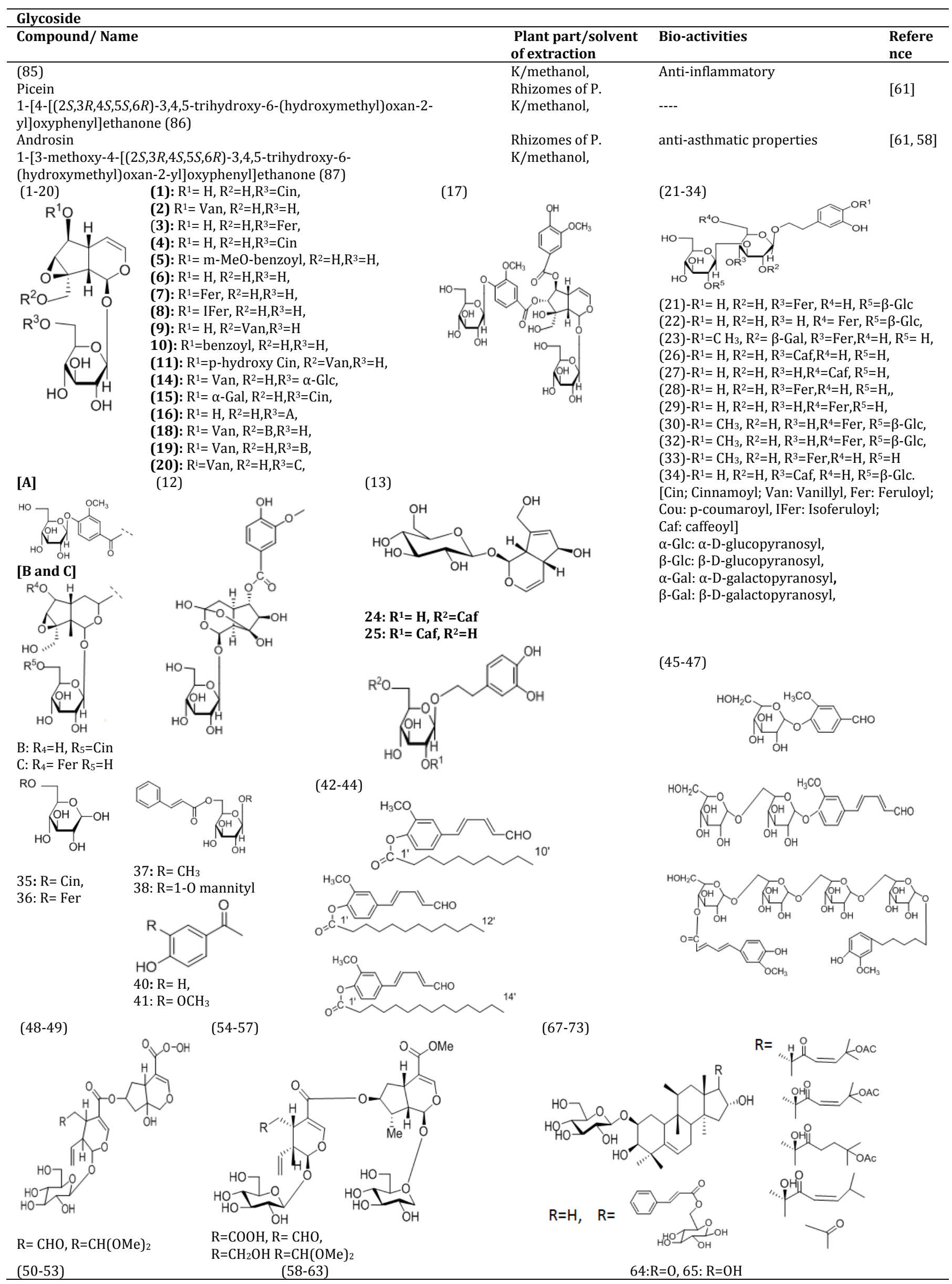




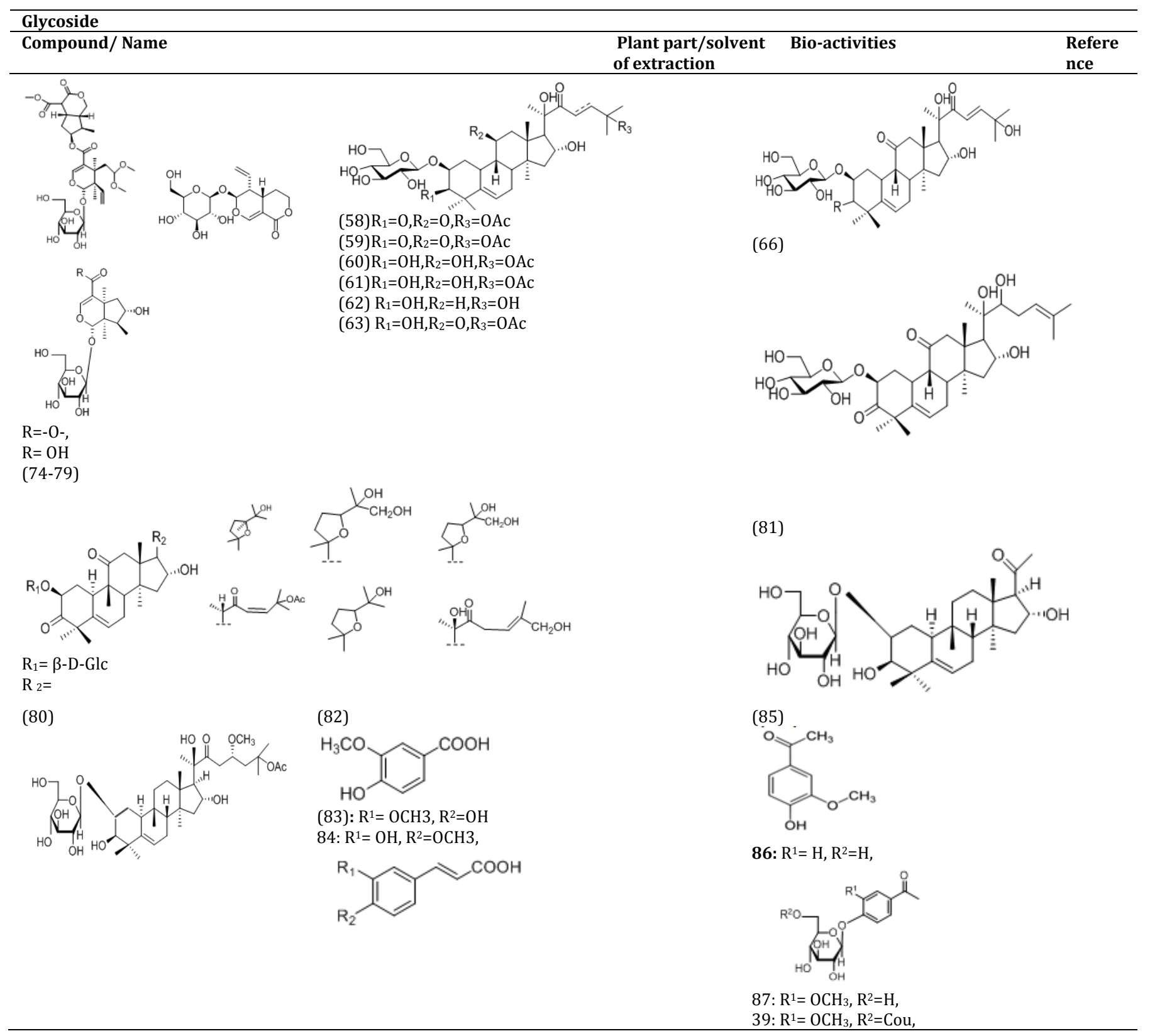

\section{Biological activates}

The wide range of biological activities of extracts and isolated chemical constitutents of P. kurroa include anti microbial [75], hepato protective [76], antioxidant activity [77], anticancer [78], anti arthritic [80], anti diabetic [87], anti-mutagenic, cardioprotective, anti-malarial, anti-inflammatory, anti-ulcer, antiasthmatic activity [79], immunomodulatory activity, hypo lipemic activity and nephro-protective activity.

\section{Antimicrobial activity}

An antimicrobial activity was observed in the ethanol and methanol extracts of Picrorhiza kurroa rhizome against selected bacterial strains. Ethanol extract of Picrorhiza kurroa rhizome showed high antibacterial activity against E. coli, B. cereus, S. aureus, K. pneumoniae, S. Typhi and, S. pyogens. The methanol rhizome extracts showed high antibacterial activity against S. aureus and P. aeruginosa, whereas acetone and hexane extract showed intermediate activity against E. coli, S. aureus, B. cereus, K. pneumoniae, S. typhi, P. aeruginosa and S. pyogens by P. Vinoth Kumar et al. [81] Usman et al., evaluated the antimicrobial potential of Picrorhiza. They conducted an in vitro study on different bacterial starins such as gram-positive bacteria-Staphylococcus aureus and Bacillus subtilis and gram-negative bacteria-Escherichia coli and Pseudomonas aeruginosa and Aspergillus niger, Malasseiza furfur and Candida albicans fungal strains. It was observed that ethanolic extract of this plant showed efficient action against all the used strains of microbes, which suggests its use an anti-microbial [82]. Antimicrobial activity of methanol extract of Picrorhiza kurroa was also investigated by Sharma et al., [83] observed that it was more potent actions against bacterial strain (E. coli, B. subtilis, S. aureus) than antibacterial drug ciprofloxacin and aqueous extract was found to be more effective against fungal strain (A. niger, C. albicans) than Fluoconazole which is a standard antifungal drug.

\section{Hepatoprotective activity}

Picroliv, possess hepatoprotective activity. Alcohol-fed rats reduced the viability of isolated hepatocytes, reduced the levels of alcoholmetabolizing enzymes (acetaldehyde dehydrogenase, aldehyde dehydrogenase) in rat hypatocytes and also produced cholestasis, as indicated by the reduction in bile volume, bile salts and bile acids. After treatment with Picroliv all these altered parameter were restored. A hydroalcholic extract of P. kurroa has been shown to be effective against 
non-alcoholic fatty liver disease by reversal of the fatty infiltration of the liver and a lowering of the quantity of hepatic lipids [84].

P. Kurroa alcoholic extract have also show hepatoprotective activity. Plant is a potent immune stimulant of both hormonal immunity and cell-mediated and shows choleretic activity in dogs. Picrorhiza kurroa is also beneficial in the management of bronchial asthma. The crude extract, and the isolated bioactive of the roots have shown to protect the liver from various types of drug-induced injury [85]. Hepatoprotective activity of Picrorhiza kurroa was investigated by Shetty et al., on male Wistar rat models. The administration of hydroalcoholic extract for $4 \mathrm{w}$ at the dosage of $200 \mathrm{mg} / \mathrm{kg}$ and 400 $\mathrm{mg} / \mathrm{kg}$ showed potent hepatoprotective actions by restoring all the changes in the liver induced in the liver [86].

\section{Anti-inflammatory activity}

Anti-inflammatory activity of extract of Picrorhiza kurroa was evaluated by Kumar et al., on rat models, suggested that this plant is a potent source of anti-inflammatory drug [87]. Apocynin possess anti-inflammatory properties. The rhizome of Picrorhiza scrophularifflora is used to treat inflammatory diseases as a traditional medication and its ethanol extract improves accelerated atherosclerosis through inhibition of redox-sensitive inflammation in rabbits [89].

\section{Immunomodulatory activity}

The effect of an ethanolic extract of the drug was studied on delayed type hypersensitivity, skin allograft rejection, humoral responses to sheep RBC and phagocytic activity of the reticuloendothelial system in mice. Picrorhiza kurroa was found to be a potent immune stimulant of both cell-mediated and humoral activity [103]. As per the Hussain et al., in vivo study report Picrorhiza kurroa is associated with immunomodulatory activities. The study was carried out on immunosuppressed mice models. Cyclophasphamide was induced in the models for immunosuppression. The study concluded that the alcoholic plant extract is significantly works on the enhancement on immunostimulant activities [90].

\section{Antioxidant activity}

Kalaivani et al., conducted an in vitro study to evaluate the antioxidant and free radical scavenging potential of Picrorhiza kurroa. It was observed that ethanolic extract of this plant showed significant anti-oxidant properties due to the presence of flavonoid and phenolic compounds [91]. The butanol extract of P. kurroa leaves were evaluated for antioxidant activity against two assays, 2,2-diphenyl-1-picrylhydrazyl radical and 2,2'-azino-bis(3ethylbenzothiazoline-6-sulphonic acid) assay. Compounds, luteolin5-0-glucopyranoside and picein were also shown the antioxidant activity by kant $e t$ al. [92]

\section{Anti-diabetic activity}

Anti-diabetic activity of Picrorhiza extract was found to lower blood glucose in laboratory animals. Chronic administration of the extract significantly reduced blood sugar in alloxan-induced diabetic rats for $10 \mathrm{~d}$. The extract was also to find to reduce the increased blood urea nitrogen and serum lipid peroxides in alloxan-induced diabetic animals and to inhibit the bodyweight reduction and leukopenia induced by alloxan administration [93]. Kumar et al., evaluated the antihyperglycemic effects and improved renal and hepatic functions in the hydroalcoholic extract of $P$. kurroa rhizome. It is observed that extract possesses increased insulin-stimulated glucose uptake potential [94]. Husain et al., conducted an in vivo study on rat models to investigate the antidiabetic potential of Picrorhiza kurroa. The models were administered with streptozotocin nicotinamide to induce diabetes mellitus. The oral administration of standardized aqueous extract effectively helped in restoring all the changes induced by streptozotocin nicotinamide which suggests Picrorhiza kurroa use as an antidiabetic agent $[95,96]$.

\section{Anticancer}

Rajeshkumar et al., conducted an in vivo study on BALB/c mice models for the evaluation of the anti-cancer activity of Picrorhiza kurroa. Sarcoma was induced by 20- methylcholanthrene (20- MC) in models and papilloma formation was initiated by 7,12 dimethylbenz[a]anthracene (DMBA) in the models. The oral administration of picroliv (100 and $200 \mathrm{mg} / \mathrm{kg}, \mathrm{p}$. o) showed inhibitory actions against 20 - MC and DMBA by decreasing sarcoma and papilloma. This study suggested that picroliv is a potent anti-cancer agent [97].

\section{Anti-mutagenic}

As per the reported study conducted by Zaberi et al., hydroalcoholic extract of Picrorhiza kurroa is associated with antimutagenic actions. It was found that hydroalcoholic extract exhibited inhibitory actions against Salmonella typhimurium MTCC 1251 and MTCC 1252 strains by direct-acting mutagen of sodium azide [98].

\section{Antiviral activity}

The n-butanol extract of Picrorhiza kurroa stems was assayed for anti-Vpr activity using TREx-HeLa-Vpr cells. Among the isolates, sylvestroside IV dimethyl acetal, saungmaygaoside D and sweroside were the most potent inhibitors with effective doses of 5 and $10 \mu \mathrm{M}$, respectively, without showing any notable cytotoxicities [99].

\section{Anti-collagenase activity}

A methanol extract of Picrorhiza kurroa rhizomes along with picrosides I II, III, and IV and 6-feruloylcatalpol, phenylethanoid glycosides, triterpene glycosides, cucurbitacin B 2-0- $\beta$-Dglucopyranoside and 25 -acetoxy-2- $\beta$-D-glucopyranosyloxy-3,16,20trihydroxy-9-methyl-19-norlanosta-5-en-22-one, and an acetophenone glycoside, picein, exhibited collagenase inhibitory activity at $10-30 \mu \mathrm{M}$, with no cytotoxicity being observed at the effective concentrations [67].

\section{RESULTS AND DISCUSSION}

Genus Picrorhiza (family Scrophulariaceae) has great importance in Ayurvedic system of medicines. Picrorhiza species accumulate cucurbitacin glucosides, iridoid glucosides, phenylethanoid glucosides, and phenolics. Its two species P. kurroa and P. scrophulariiflora have so much similarity due to the presence of similar active constituents like picroside-I, picroside-II, kutkoside while P. scrophulariiflora contains some additional phenylethanoid glycoside and plantamajoside, which are absent in the species $\mathrm{P}$. kurroa. So, the P. scrophulariiflora is closely related to P. kurroa and used as a substitute or adulterants. Thus, reviewing the genus Picrorhiza it is clear that the lot of work has been done on species P. kurroa in comparison to other species P. scrophulariiflora. However, more research is needed to know about the chemical constituents of P. scrophulariiflora and its biological activities.

\section{ACKNOWLEDGEMENT}

I am grateful to my Institution Head for providing me all sorts of help to make this review. I am also thankful to my friends who have helped a lot by giving the inspiration and support throughout the investigation.

\section{FUNDING}

Nil

\section{AUTHOR CONTRIBUTION}

All the work has been carried out by me.

\section{CONFLICTS OF INTERESTS}

Declared none

\section{REFERENCES}

1. Samant SS, Dhar U, Palni LMS. Medicinal plants of Indian Himalaya: diversity, distribution and potential value. Nainital: Gyano-daya Prakashan; 1998. p. 163.

2. Daniel AD, Urban S, Ute R. A historical overview of natural products in drug discovery, Metabolities. 2012 June;2(2):303-36.

3. Prajapati ND, Purohit SS, Sharma AK, Kumar T. A handbook of medicinal plants: A complete sourcebook. Jodhpur, India: Agrobios; 2003. p. 396-7. 
4. Jain SK, De Fillips RA. Medicinal plants of India. Vol. 2. Algonac, (MI): Reference Publications; 1991. p. 558.

5. Varier PS. Indian medicinal plants. A compendium of 500 species. Vol. 4. Hyderabad, India. Orient Longman; 1995. p. 269-72.

6. Singh DK, Hajra PK. Floristic diversity. In: Gujral GS, Sharma V. Editors V. Changing perspective of biodiversity status in the Himalaya, British Council Division, Wildlife Youth Services. New Delhi: British High Commission Publication; 1996. p. 2338.

7. Kumar N, Kumar T, Sharma SK. Phytopharmacological review of genus picrorhiza. Int $\mathrm{J}$ Univers Pharm Bio Sci. 2013;2(4):334-41.

8. Ramakrishna A, Ravishankar GA. Influence of abiotic stress signals on secondary metabolites in plants. Plant Signal Behav. 2011 November 1;6(11):1720-31. doi: 10.4161/psb.6.11.17613, PMID 22041989.

9. Jan R, Asaf S, Numan M, Lubna, Kim K. Plant secondary metabolite biosynthesis and transcriptional regulation in response to biotic and abiotic stress conditions. Agronomy. 2021;11(5):968-99. doi: 10.3390/agronomy11050968.

10. Sharma PV. Classical uses of medicinal plants. Varanasi: Chaukhambha Visvabharati; 1996. p. 69-70.

11. Mishra BB, Tiwari VK. Natural products: an evolving role in future drug discovery. Eur J Med Chem. 2011;46(10):4769-807. doi: 10.1016/j.ejmech.2011.07.057, PMID 21889825.

12. Rey-Ladino J, Ross AG, Cripps AW, McManus DP, Quinn R. Natural products and the search for novel vaccine adjuvants. Vaccine. 2011;29(38):6464-71.

doi: 10.1016/j.vaccine.2011.07.041, PMID 21787827.

13. Cragg GM, Newman DJ. Biodiversity: A continuing source of novel drug leads. Pure Appl Chem. 2005;77(1):7-24. doi: 10.1351/pac200577010007.

14. Haefner B. Drugs from the deep: marine natural products as drug candidates. Drug Discovery Today. 2003;8(12):536-44. doi: 10.1016/s1359-6446(03)02713-2, PMID 12821301.

15. Butler MS. The role of natural product chemistry in drug discovery.J Nat Prod. 2004;67(12):2141-53. doi: 10.1021/np040106y, PMID 15620274.

16. Gurib-Fakim A. Medicinal plants: traditions of yesterday and drugs of tomorrow. Mol Aspects Med. 2006;27(1):1-93. doi: 10.1016/j.mam.2005.07.008, PMID 16105678.

17. Simbo DJ. An ethnobotanical survey of medicinal plants in Babungo, Northwest Region, Cameroon. J Ethnobiol Ethnomed. 2010;6:8. doi: 10.1186/1746-4269-6-8, PMID 20156356.

18. Chintamunnee V, Mahomoodally MF. Herbal medicine commonly used against non-communicable diseases in the tropical island of Mauritius. J Herb Med. 2012;2(4):113-25. doi: 10.1016/j.hermed.2012.06.001.

19. Ekor M. The growing use of herbal medicines: issues relating to adverse reactions and challenges in monitoring safety. Front Pharmacol. 2014;4:177. doi: 10.3389/fphar.2013.00177, PMID 24454289.

20. Joshi RK, Satyal P, Setzer WN. Himalayan Aromatic Medicinal Plants: A Review of their Ethnopharmacology, Volatile Phytochemistry, and Biological Activities. Medicines (Basel). 2016;3(1):1-55. doi: 10.3390/medicines3010006, PMID 28930116.

21. Polunin 0, Stainton A. Flowers of the Himalayas. 6th ed. Oxford: Oxford University Press; 1990. p. 295.

22. Dharam Chand M, Zubair A, Nautiyal MC. Conservation of Picrorhiza kurrooa through cultivation in Garhwal Himalaya: a review. J Herb Med. 2016;4(1):64-9.

23. Atal CK, Sharma ML, Kaul A, Khajuria A. Immunomodulating agents of plant origin. I: preliminary screening. Journal of Ethnopharmacology. 1986;18(2):133-41. doi: 10.1016/03788741(86)90025-5.

24. Joy KL, Kuttan R. Anti-diabetic activity of Picrorrhiza Kurroa extract. J Ethnopharmacol. 1999;67(2):143-8. doi: 10.1016/s0378-8741(98)00243-8, PMID 10619377.

25. Lee HS, Yoo CB, Ku SK. Hypolipemic effect of water extracts of Picrorrhiza kurroa in high fat diet treated mouse. Fitoterapia. 2006;77(7-8):579-84. doi: 10.1016/j.fitote.2006.09.004. PMID 17056204 .
26. Baruah CC, Gupta PP, Nath A, Patnaik LGK, Dhawan BN. Antiallergic and anti-anaphylactic activity of picroliv- a standardised iridoid glycoside fraction ofpicrorhiza kurroa. Pharmacol Res. 1998;38(6):487-92. doi: 10.1006/phrs.1998.0397.

27. Mittal N, Gupta N, Saksena S, Goyal N, Roy U, Rastogi AK. Protective effect of picroliv from Picrorhiza kurroa against Leishmania donovani infections in Mesocricetus auratus. Life Sci. 1998;63(20):1823-34. doi: 10.1016/s00243205(98)00456-1, PII S0024-3205(98)00456-1. PMID 9820126.

28. Gaddipati JP, Madhavan S, Sidhu GS, Singh AK, Seth $P$, Maheshwari RK. Picroliv- a natural product protects cells and regulates the gene expression during hypoxia/reoxygenation. Mol Cell Biochem. 1999;194(1-2):271-81. doi 10.1023/a:1006982028460, PMID 10391150.

29. Stuppner H, Wagner $\mathrm{H}$. New cucurbitacin glycosides from Picrorhiza kurroa. Plant med. 1989;55:559.

30. Wagnes K, Kloss $\mathrm{P}$, Henkels WD. Natural products from medicinal plants. XVII. Picroside II, a new 6-vanilloyl-catapol from Picrorhiza kurroa Royle and Benth, Justus Liebigs. Ann Chim 1972;759:173-82.

31. Sukhdev SH. Indian Herbal pharmacopoeia. Vol. I. Indian Drug Manufacturing Association; 2002. p. 106.

32. Laurie WA, McHale D, Sheridan JB. A cucurbitacin glycoside from Picrorhiza kurrooa. Phytochemistry. 1985;24(11):265961. doi: 10.1016/S0031-9422(00)80688-3.

33. Indian herbal pharmacopoeia, a revised new edition. Mumbai: Indian Drugs Manufacturers Association; 2002. p. 289-97.

34. Chander R, Kapoor NK, Dhawan BN. Picroliv, picroside-I and kutkoside from Picrorhiza kurrooa are scavengers of superoxide anions. Biochem Pharmacol. 1992;44(1):180-3. doi: 10.1016/0006-2952(92)90054-m, PMID 1321626.

35. Bantawa P, Ghosh SK, Bhandari P, Singh B, Ghosh PB, Ahuja PS, Mondal TK. Micropropagation of an elite line of Picrorhiza scrophulariiflora, Pennell, an endangered high valued medicinal plant of the Indo-China Himalayan region. Med Aromatic Plant Sci Biotechnol. 2010;4(1):1-7.

36. Anandan R, Deepa Rekha RD, Saravanan N, Devaki T. Protective effects of Picrorrhiza kurroa against $\mathrm{HCl} /$ ethanol-induced ulceration in rats. Fitoterapia. 1999b;70(5):498-501. doi: 10.1016/S0367-326X(99)00081-7.

37. Joy KL, Rajeshkumar NV, Kuttan G, Kuttan R. Effect of Picrorrhiza kurroa extract on transplanted tumours and chemical carcinogenesis in mice. J Ethnopharmacol. 2000;71(12):261-6. doi: 10.1016/S0378-8741(00)00168-9.

38. Li P, Matsunaga K, Yamakuni T, Ohizumi Y. Potentiation of nerve growth factor-action by picrosides I and II, natural iridoids, in PC12D cells. Eur J Pharmacol. 2000;406(2):203-8. doi: 10.1016/S0014-2999(00)00662-2.

39. Khajuria A, Gupta A, Singh S, Malik F, Singh J, Suri KA, Satti NK, Qazi GN, Srinivas VK, Gopinathan, Ella K. RLJ-NE-299A: a new plant based vaccine adjuvant. Vaccine. 2007;25(14):2706-15. doi: 10.1016/j.vaccine.2006.06.036. PMID 16872726.

40. Shukla B, Visen PK, Patnaik GK, Dhawan BN. Choleretic effect of picroliv, the hepatoprotective principle of Picrorhiza kurroa. Planta Med. 1991;57(1):29-33. doi: 10.1055/s-2006-960010, PMID 2062954.

41. Coventry BO. Wild flowers of Kashmir. Vol. 2. Dehra Dun: Bishen Singh Mahendra Pal Singh; 1927. p. 89-90.

42. Chettri. Non-timber forest produces utilization, distribution and status in atrekking corridor of Sikkim, India. Lyonia 2005;8(1):93-108.

43. Hooker JD. The flora of British India. Vol. 4. Dehra Dun: Bishen Singh Mahendra Pal Singh, Dehra Dun; 1990. p. 290.

44. Kitagawa I, Hino K, Nishimura T. Mukai E, Yosioka I, Inouye, H, Yoshida, T. Picroside I, A bitter principle of Picrorhiza kurrooa. Tetrahedron Letters 1969;10(43):3840.

45. Sultan P, Jan A, Pervaiz Q. Phytochemical studies for quantitative estimation of iridoid glycosides in Picrorhiza kurroa Royle. Bot Stud. 2016;57(1):7. doi: 10.1186/s40529016-0121-2. PMID 28597416.

46. Singh N, Gupta AP, Singh B, Kaul VK. Quantification of Picroside-I and Picroside-II in Picrorhiza kurroa by HPTLC. 
Journal of Liquid Chromatography and Related Technologies. 2005;28(11):1679-1691. doi: 10.1081/JLC-200060439.

47. Gaikwad PS, Bhope SG, Kuber VV, Patil MJ. Validated TLC method for simultaneous quantitation of kutkoside and picroside-I from kutki extract. Phytochemical Analysis: PCA. 2011;22(1):36-41. doi: 10.1002/pca.1248, PMID 20821813.

48. Stuppner $\mathrm{H}$, Wagner $\mathrm{H}$. New cucurbitacin glycosides from Picrorhiza kurroa. Plant Med 1989;55:559.

49. Rastogi RP, Sharma VN, Siddiqui S. Chemical examination of Picrorhiza kurroa Benth--Part 1. J Sci Ind Res. 1949;8B:173-8.

50. Laurie WA, McHale D, Sheridan JB. A cucurbitacin glycoside from Picrorhiza kurrooa. Phytochemistry. 1985;24(11):265961. doi: 10.1016/S0031-9422(00)80688-3.

51. Li JX, Li P, Tezuka Y, Namba T, Kadota S. Three phenylethanoid glycosides and an iridoid glycoside from Picrorhiza scrophulariiflora. Phytochemistry. 1998;48(3):537-42. doi: 10.1016/s0031-9422(98)00030-2, PMID 9654780.

52. Wang H, Ye WC, Jiang RW, Wu JJ, Mak TC, Zhao SX, Yao XS. Three new cyclopentanoid monoterpenes from Picrorhiza scrophulariiflora. Planta Med. 2004;70(4):382-4. doi: 10.1055/s-2004-818957, PMID 15095161.

53. Zhu TF, Huang KY, Deng XM, Zhang Y, Xiang H, Gao HY, Wang da C. Three new caffeoyl glycosides from the roots of Picrorhiza scrophulariiflora. Molecules. 2008;13(4):729-35. doi: 10.3390/molecules13040729, PMID 18463574.

54. Kitagawa I, Hino K, Nishimura T, Iwata E, Yosioka I. On the constituents of picrorhiza kurrooa. (1). The structure of picroside i, a bitter principle of the subterranean part. Chem Pharm Bull. 1971;19(12):2534-44. doi: 10.1248/cpb.19.2534.

55. Kitagawa I, Hino K, Nishimura T Mukai E, Yosioka I, Inouye H, Yoshida T. Picroside I, A bitter principle of Picrorhiza kurrooa. Tetrahedron Letters 1969;10(43):3840.

56. Lohani H, Gwari G, Andola HC, Chauhan N. High performance liquid chromatographic determination of Picroside I and II in Picrorhiza kurroa Royle ex Benth. A critically endangered plant of Himalaya. Med Plants. 2010;3:165-7.

57. Weinges K, Kloss P, Henkels W-D. Naturstoffe aus Arzneipflanzen, XVII. Picrosid-II, ein neues 6-Vanilloyl-catalpol aus Picrorhiza kurrooa Royle und Benth. Justus Liebigs Ann Chem. 1972;759(1):173-82. doi: 10.1002/jlac.19727590113.

58. Wang DQ, He ZD, Feng BS, Yang CR. Chemical constituents from Picrorhiza scrophulariiflora. Acta Bot Yunnan. 1993;15:83-8.

59. Weinges K, Künstler K. Notiz über die Isolierung und Konstitutionsaufklärung eines neuen Picrosids aus Picrorhiza kurroa Royle und Benth. Liebigs Ann Chem. 1977:1053-7.

60. Simons JM, 't Hart L, van Dijk H, de Silva K, Labadie R. Isolation of five low molecular compounds from a root extract of picrorhiza kurroa which affect the respiratory burst in activated human polymorphonuclear leucocytes. Planta Med. 1989;55(1):113. doi: 10.1055/s-2006-961892.

61. Stuppner H, Wagner H. Minor iridoid and phenol glycosides of Picrorhiza kurroa; 1989b.

62. Singh B, Rastogi RP. Chemical examination of Picrorhiza kurroa Benth. Part VI; 1972.

63. Li JX, Li P, Tezuka Y, Namba T, Kadota S. Three phenylethanoid glycosides and an iridoid glycoside from Picrorhiza scrophulariiflora. Phytochemistry 1998;48(3):537-42. doi: 10.1016/s0031-9422(98)00030-2, PMID 9654780.

64. Jia $Q$, Hong MF, Minter D. Pikuroside: a novel iridoid from Picrorhiza kurroa. J Nat Prod. 1999;62(6):901-3. doi: 10.1021/np980493+, PMID 10395515.

65. Stuppner $\mathrm{H}$, Wagner $\mathrm{H}$. New cucurbitacin glycosides from Picrorhiza kurrooa. Planta Med. 1989a;55(6):559-63. doi: 10.1055/s-2006-962095, PMID 2616673.

66. Morikawa $\mathrm{T}$, Nakanishi $\mathrm{Y}$, Inoue $\mathrm{N}$, Manse $\mathrm{Y}$, Matsuura $\mathrm{H}$, Hamasaki S, Yoshikawa M, Muraoka O, Ninomiya K. Acylated iridoid glycosides with hyaluronidase inhibitory activity from the rhizomes of Picrorhiza kurroa Royle ex Benth. Phytochemistry. 2020;169:112185. doi: 10.1016/j.phytochem.2019.112185.

67. Morikawa T, Inoue N, Nakanishi Y, Manse Y, Matsuura H, Okino K, Hamasaki S, Yoshikawa M, Muraoka O, Ninomiya K. Collagen synthesis-promoting and collagenase inhibitory activities of constituents isolated from the rhizomes of Picrorhiza kurroa Royle ex Benth. Fitoterapia. 2020;143, June:104584. doi: 10.1016/j.fitote.2020.104584, PMID 32247053.

68. Ali M, Sultana S, Mir Rasool S. Chemical Constituents from the Roots of Picrorhiza kurroa Royle ex Benth. Int J Pharm Pharm Sci. 2017;9(3):25-35.

69. Khine LW, Winc YY, Ngwec H, Ikuro A, Hiroyuki M. Bis-iridoid and iridoid glycosides: Viral protein $\mathrm{R}$ inhibitors from Picrorhiza kurroa collected in Myanmar. Fitoterapia. 2019;134:101-7.

70. Stuppner H, Kählig H, Seligmann O, Wagner H. Minor cucurbitacin glycosides from Picrorhiza kurrooa. Phytochemistry. 1990;29(5):1633-7. doi: 10.1016/0031-9422(90)80136-5.

71. N Sharma-Himalayan medicinal plants. Elsevier; 2021-.

72. Sah JN, Varshney VK. Chemical constituents of Picrorhiza genus: a review. Am J Essent Oeil. 2013;1(2):22.

73. Huang KY, He L, Qu Y, Gao HY, Deng XM, Wu LJ. Isolation and identification of chemical constituents from roots of Picrorhiza scrophulariiflora Pennell. Shenyang Yaoke Da Xue Xuebao. 2009;26(2):112-15

74. Basu K, Dasgupta B, Bhattacharya SK, Debnath PK. Chemistry and pharmacology of apocynin, isolated from Picrorhiza kurrooa Royle ex Benth. Curr Sci. 1971;22:603-4.

75. Mohammed R, Mohammed U, Yamgar S, Gadgoli C, Salunkhe D. Preliminary screening and antimicrobial activity of Picrorhiza kurroa Royle ethanolic extracts. Int J Pharm Sci Rev Res. 2012;14(1):73-6.

76. K N, G PK, Y C, Kr A. Evaluation of potassium dichromate (K2Cr207)-induced liver oxidative stress and ameliorative effect of Picrorhiza kurroa extract in Wistar albino Rats. Biol Trace Elem Res. 2018;184(1):154-64. doi: 10.1007/s12011017-1172-2, PMID 28990134.

77. Rajkumar V, Guha G, Kumar RA. Antioxidant and antineoplastic activities of Picrorhiza kurroa extracts. Food Chem Toxicol. 2011;49(2):363-69. doi: 10.1016/j.fct.2010.11.009, PMID 21081148.

78. Rathee D, Thanki M, Bhuva S, Anandjiwala S, Agrawal R. Iridoid glycosides-Kutkin, Picroside I, and Kutkoside from Picrorrhiza kurroa Benth inhibits the invasion and migration of MCF-7 breast cancer cells through the down regulation of matrix metalloproteinases. Arab J Chem. 2013;6(1):49-58. doi: 10.1016/j.arabjc.2011.01.011

79. Kumar V, Sood H, Chauhan RS. Optimization of a preparative RP-HPLC method for isolation and purification of picrosides in Picrorhiza kurroa. J Plant Biochem Biotechnol. 2016;25(2):208-14. doi: 10.1007/s13562-015-0327-5.

80. Husain GM, Rai R, Rai G, Singh HB, Thakur AK, Kumar V. Potential mechanism of anti-diabetic activity of Picrorhiza kurroa. Tang. 2014;4(4):1-5.

81. Vinoth Kumar P, Sivaraj A, Madhumitha G, Saral AM, Senthil Kumar B. Int J Curr Pharm Res. 2010;2(1):30-3.

82. Usman M, Surekha Y, Chhaya G, Devendra S. Preliminary screening and antimicrobial activity of Picrorhiza kurroa Royle ethanol extracts. Int J Pharm Sci Rev Res. 2012;14:73-6.

83. Sharma SK, Kumar N. Antimicrobial screening of Picrorhiza kurroa Royle ex Benth rhizome. Int J Curr Pharm Rev Res. 2012;3:60-5.

84. Picrorrhiza root: pharmacology. Available from: http://www.mdidea.com/products/new/new04806.html. [Last accessed on 20 Sep 2011].

85. Manjeshwar SB, Shivashankara AR, Venkatesh S, Harshith PB, Palatty PL, Bhandari Rao. Chapter 7-phytochemicals in the prevention of ethanol-induced hepatotoxicity: A revisit. G. S Dietary Interventions in Liver Disease Foods, Nutrients, and Dietary Supplements. 2019 Chapter 7-Phytochemicals in the Prevention of Ethanol-Induced Hepatotoxicity: A Revisit; 2019. p. 79-89.

86. Shetty SN, Mengi S, Vaidya R, Vaidya AD. A study of standardized extracts of Picrorhiza kurroa Royle ex Benth in experimental nonalcoholic fatty liver disease. Journal of Ayurveda and integrative mMedicine. 2010 July; 1(3):203-10. doi: 10.4103/0975-9476.72622, PMID 21547049.

87. Singh GB, Bani S, Singh S, Kaul A, Khajuria A, Sharma ML, Gupta BD, Banerjee SK, Singh GB, Bani S, Singh S, Khajuria A, Sharma ML, Gupta BD, Banerjee SK. Antiinflammatory activity of the 
iridoids kutkin, picroside-1 and kutkoside from Picrorhiza kurrooa. Phytother Res. 1993;7(6):402-7. doi: $10.1002 / p t r .2650070604$.

88. Li JX, Li P, Tezuk Y, Namba T, Kadota SLi JX, Li P. Three phenylethanoid glycosides and an iridoid glycoside from picrorhiza scrophulariiflora. Phytochemistry. 1998;48(3):5372. doi: 10.1016/s0031-9422(98)00030-2, PMID 9654780.

89. Engels F, Renirie BF, Hart BA, Labadie RP, Nijkamp FP, 't Hart BA, Labadie RP, Nijkamp FP. Effects of apocynin, a drug isolated from the roots of Picrorhiza kurroa, on arachidonic acid metabolism. FEBS Lett. 1992;305(3):254-6. doi: 10.1016/0014-5793(92)80680-f, PMID 1299626.

90. Hussain A, Shadma W, Maksood A, Ansari SH. Protective effects of Picrorhiza kurroa on cyclophosphamide-induced immunosuppression in mice. Pharmacognosy. Pharmacognosy Res. 2013;5(1):30-5. doi: 10.4103/0974-8490.105646, PMID 23598922.

91. Kalaivani T, Rajasekaran C, Mathew L. In vitro free radical scavenging potential of Picrorhiza kurroa. J Pharm Res. 2010 April;3(4):849-54.

92. Kant K, Walia M, Agnihotri VK, Pathania V, Singh B. Evaluation of aantioxidant aactivity of picrorhiza kurroa (Leaves) eextracts. Indian J Pharm Sci. 2013, May;75(3):324-9. doi: 10.4103/0250-474X.117438, PMID 24082348.

93. Krupashree K, Hemanth Kumar K, Rachitha P, Jayashree GV, Khanum F. Chemical composition, antioxidant and macromolecule damage protective effects of Picrorhiza kurroa Royle ex Benth. S Afr J Bot. 2014;94:249-54. doi: 10.1016/j.sajb.2014.07.001.

94. Kumar S, Patial V, Soni S, Sharma S, Pratap K, Kumar D, Padwad Y. Picrorhiza kurroa enhances $\beta$-cell mass proliferation and insulin secretion in streptozotocin evoked $\beta$-cell damage in rats. Front Pharmacol. 2017;8(537):1-15. doi: 10.3389/fphar.2017.00537.

95. Husain GM, Singh PN, Kumar V. Antidiabetic activity of standardized extract of Picrorhiza kurroa in rat model of NIDDM. Drug Discoveries Therapeutics. 2009;3(3):88-92. PMID 22495535.
96. Sehgal R, Chauhan A, Gilhotra UK, Gilhotra A. In vitro and in vivo evaluation of antiasthmatic activity of Picrorhiza kurroa plant. International Journal of Pharmaceutical Sciences and Research. 2013; September;4(9):3440.

97. Rajeshkumar NV, Kuttan R. Protective effect of Ppicroliv, the active constituent of Picrorhiza kurroa, against chemical carcinogenesis in mice. Teratogenesis Carcinogenesis Mutagenesis. 2001;21(4):303-13. doi: 10.1002/tcm.1018, PMID 11406836.

98. Zaveri M, Patel P, Dhru B, Patel S. Screening of in vitro antimutagenic activity of selected plants. Am J Pharm Tech Res. 2011;1:232-43.

99. Win NN, Kodama T, Lae KZW, Win YY, Ngwe H, Abe I, Morita H, Wynn, Win YY, Ngwe H, Abe I. C13, Bis-iridoid and iridoid glycosides: Viral protein R inhibitors from Picrorhiza kurroa collected in Myanmar. Bis-iridoid and iridoid glycosides: viral protein $\mathrm{R}$ inhibitors from Picrorhiza kurroa collected in Myanmar. Fitoterapia. 2019 April;134:101-10101-7. doi: 10.1016/j.fitote.2019.02.016, PMID 30794917.

100. Mulliken T, Crofton P. Review of the status, harvest, trade and management of seven Asian CITES-listed medicinal and aromatic plant species. Federal Agency Nature Conservation; 2008. p. 61-4.

101. Didry N, Seidel V, Dubreuil L, Tillequin F, Bailleul F. Isolation and antibacterial activity of phenylpropanoid derivatives from Ballota nigra. J Ethnopharmacol. 1999;67(2):197-202. doi: 10.1016/s0378-8741(99)00019-7, PMID 10619384.

102. Calis I, Kirmizibekmez H, Rüegger H, Sticher O. Phenylethanoid glycosides from globularia trichosantha. J Nat Prod 1999;62(8):1165-8. doi: 10.1021/np9900526, PMID 10479329.

103. Lin HCC, Ding HYY, Ko FNN, Teng CMM, Wu YCC. Aggregation inhibitory activity of minor acetophenones from Paeonia species. Planta Med. 1999;65(7):595-9. doi: 10.1055/s-1999 14030, PMID 10575372.

104. Prakash V, Kumar A, Kaur H, Kumar M, Gupta S, Bala R. Chemical constituents and biological activities of genus picrorhiza: an update. Indian J Pharm Sci 2020;82:562-77. 